\title{
Like an eagle carries its young
}

Author:
Hans-Georg Wünch ${ }^{1,2}$
Affiliation:
'Theologisches Seminar
Rheinland, Germany
2Department of Biblical and
Ancient Studies, University of
South Africa, South Africa
Corresponding author:
Hans-Georg Wünch,
hans-georg.wuench @tsr.de
Dates:
Rede with your
Received: 10 Nov. 2015
Accepted: 01 Feb. 2016
Published: 15 July 2016
to read online.
How to cite this article:
Wünch H.-G., 2016, 'Like an
eagle carries its young',
HTS Teologiese Studies/
Theological Studies $72(3)$,
a3249. http://dx.doi.
org/10.4102/hts.v72i3.3249
Copyright:
la 2016. The Authors.
Licensee: AOSIS. This work
is licensed under the
Creative Commons
Attribution License.

The picture of an eagle carrying its young on its wings (Dt 32:11) is a powerful and encouraging image of trust and security in God. It is particularly relevant for Western culture, where the eagle is a prominent symbol of power and strength. In recent years, though, the translation of the Hebrew term more accurately translated as 'vulture'. But can this really be a symbol of comfort? Furthermore, do eagles (or vultures) even carry their young on their wings? This article intends to shed some light on these questions.

\section{Introduction}

Eagles are really impressive birds. We often call them the 'king of the air' and, indeed, the Yoruba in Nigeria have a proverb which says: 'the eagle is the father of birds of prey' (Mieder 1986:131). In the Reichstag - the German parliamentary building - an image of an eagle fills one wall. We call it the 'federal eagle'. Germany is by no means the only country which uses an eagle as its symbol. In the Roman Empire, the eagle was as much a symbol of the state, as it is in the United States today, where an eagle is the dominant figure on the 'Great Seal of the United States'.

In the Old Testament (OT), the eagle is also used as a symbol. The Hebrew term wiְֶ, which is usually translated as 'eagle', is found 28 times in the OT (Kiuchi 1997:200). In only nine places (Lv 11:13; Dt 14:12; Ez 1:10; 10:14; Job 39, 27; Pr 30:17.19; Dn 4:30; 7:4) does it refer simply to the bird itself. In one of these examples, Leviticus 11:13, we learn that the eagle is one of the unclean animals. In the other cases, however, the eagle is used as a symbol or as an analogy and usually represents speed, strength, security and care. We will look at these various aspects later.

In Exodus 19:4 and Deuteronomy 32:11 the eagle represents God and his loving care towards Israel. In both descriptions we read about God bringing his people out of Egypt and into Canaan as if on the wings of an eagle. We will look especially at the text in Deuteronomy, as there are a lot of questions that arise from this verse. One of these concerns whether the translation of the Hebrew term ְֶּ as 'eagle' is correct, or whether it should be rather translated as 'vulture'. Then there is the question of what exactly this נְשֶׁ does to - or for - its young. Many translations of the first half of the verse in Deuteronomy say that the ְֶֶׁ 'stirs up its nest' (ESV, NIV, NAS and others). Some translations, such as the Common English Bible, read: 'Like an eagle protecting its nest'. Which is the correct translation? Finally, we have to ask how the picture of an eagle carrying its young on its wings should be understood. Is this something we can really verify in nature? Does the text really imply that this is really something that the נְשֶׁ does?

We will now first look at the image of the נֶׁ in the Old Testament (OT). At this stage we will not distinguish between eagle and vulture - for convenience sake, however, we will refer to נֶֶֶ as 'eagle'. What characteristics does this image reflect? What characteristics did a man or woman in OT times associate with the eagle? We should not jump too quickly from our own associations to the Biblical ones; as they might differ greatly from each other. By way of illustration, the fox in our Western culture is a symbol of cleverness, but in Biblical times it was a useless animal considered more or less as vermin ${ }^{1}$. So what associations did people have with the eagle in Biblical times?

\section{The image of the eagle in the Old Testament Speed}

The first aspect of the image of an eagle that we examine is that of speed. This might not be the first thing that we would associate with an eagle today, but imagine, just for a moment, a time in which human beings were restricted to their own physical abilities. The only way for a human to be faster than he or she could be simply by running was to use a horse (or a camel). Therefore, we 1.See Sol 2:15. Compare also Strack \& Billerbeck 1924:201; Bovon 1996:450. 
find many passages in the OT where the speed of horses is mentioned. God asks Jeremiah: 'If you have raced with men on foot and they have worn you out, how can you compete with horses?' (Jr 12:5). Habakkuk describes the Babylonian army with these words: 'Their horses are swifter than leopards ...' (Hab 1:8a).

However, nothing in Biblical times could be compared to the swiftness of an eagle. Today we are accustomed to travelling using cars, motorcycles and even aircraft and we can travel great distances in a few hours. In Biblical times, though, the fastest animal (at least when it came to greater distances) was the eagle. Nothing could hinder it. It would just fly over it. There are a few very interesting videos on YouTube taken using a video camera mounted on the back of an eagle. This enables us to accompany the eagle as it flies (see, e.g., https:/ / www.youtube.com/watch?v=2EAgbW1u00M).

When watching videos like these, one wonders how it would be to have to cross the same distance on foot or even on horseback. One automatically thinks of Deuteronomy 28:49, where we read: 'The Lord will bring a nation against you from far away, from the ends of the earth, like an eagle swooping down ...'

\section{Strength}

The second aspect of the image of an eagle addressed in the OT is that of strength. It is not the strength of a lion or a bear, but the power to overcome obstacles. We see this, for example, in the well-known verses in Isaiah:

... those who hope in the LORD will renew their strength. They will soar on wings like eagles; they will run and not grow weary, they will walk and not be faint. (Is 40:31)

Psalm 103:5, meanwhile, describes the Lord as one "who satisfies your desires with good things so that your youth is renewed like the eagle's.

Further, illustrating the strength of the eagle is the example of the Golden Eagle which weighs around six kilograms and is able to carry a prey up to almost twice its own weight (Dröscher 1978:272).

\section{Security}

The third aspect of the image of an eagle that we will look at is found in the fact that, in Biblical times, there was almost no possibility of hunting an eagle. Eagles were vulnerable only when they were down on the ground or flying very low - but they could easily fly higher than any human technology those days could match.

Again we have to think of another time where the possibilities of reaching something at a distance were very restricted. There was the spear and the bow for use in war time and for hunting, and David had his sling which he used to kill Goliath. When a bird was high in the air, though, nothing could reach it. Therefore eagles - and their nests in the high mountain ranges - were a symbol of security.
This security might be false, as in Jeremiah 49:16, where God reproves the nations for the pride of their hearts with the words: 'Though you build your nest as high as the eagle's, from there I will bring you down,' (see Obadiah 1:4). While in the eyes of God there is no security in such places, for humans the nest of the eagle resembles security at its best!

\section{Care}

There is a fourth aspect to the image of the eagle in the OT. It is not as prominent as the others, but we can still find it, particularly in Deuteronomy 32:11. This is the aspect of the eagle taking care of its young. This is especially wellexpressed in the spreading of the wings over the young eaglets. This action is also expressed in many other places in the OT where the eagle is not directly mentioned (see Grisanti 2012:786).

When Ruth accompanies her mother-in-law, Naomi, to Israel and decides to make the people of Naomi her people and the God of Naomi her God, Boaz describes this with the words:

May the Lord repay you for what you have done. May you be richly rewarded by the Lord, the God of Israel, under whose wings you have come to take refuge. (Rt 2:12)

Only the eagle, as the 'king of the birds' and a symbol of speed, strength, security and care, could possibly have inspired this picture of taking refuge 'under wings'. The same picture is found in Ezekiel 16:8 and also in many Psalms. For example, Psalm 36:8: 'How priceless is your unfailing love, O God! People take refuge in the shadow of your wings.'

Now that we have identified each of these aspects connected with the image of the eagle we turn to Deuteronomy 32:11. To understand this verse it is necessary to also read verses 9 and 10:

For the Lord's portion is his people, Jacob his allotted inheritance. In a desert land he found him, in a barren and howling waste. He shielded him and cared for him; he guarded him as the apple of his eye, like an eagle that stirs up its nest and hovers over its young, that spreads its wings to catch them and carries them aloft. (Dt 32:9-11)

\section{Deuteronomy 32:11 Eagle or vulture?}

The first question we have to answer is, whether the Hebrew term stands for 'eagle' or 'vulture'. Many scholars argue in favour of it being the vulture. The NIV Background Commentary of the Old Testament, for example, states: 'Though the eagle cannot be ruled out, the bird named here is more usually taken to be the griffin [sic] vulture, with a wingspan of eight to ten feet.' (Walton, Matthews \& Chavalas 2000:94). William H. Propp, in his commentary on Exodus also writes: 'Both etymology (Arabic na/isr) and ornithology favour this rendering of nešer over the more comfortable "eagle".' (Propp 2006). In her book All the birds of the Bible, Alice Parmelee argues that נֶֶׁ usually stands for the 'griffon vulture (sometimes the golden eagle)' (Parmelee 1959:106). 
Others are more in favour of the translation 'eagle', but usually see 'vulture' as a possible translation in some passages. Roy Pinney, in his book The animals in the Bible, states: 'The Hebrew word נֶֶׁ occurs with great frequency in the Old Testament. While it is usually translated as eagle, Tristam argues in favour of putting the griffon vulture, a bird more like the eagle than the vulture in its traits and habits, in its place. The argument need not be resolved to point out the fascination of the ancients with large birds of prey' (Pinney 1964:147).

One of the strongest arguments in favour of the vulture is Micah 1:16: 'Shave your head in mourning for the children in whom you delight; make yourself as bald as the vulture, for they will go from you into exile.' Most exegetes argue that this picture can apply only to the vulture because the eagle is not bald. When we look at a picture of the griffon vulture, however, which is usually identified as the bird in view here, this may be doubted (see, for example, https:/ / en.wikipedia. org/wiki/Vulture). His neck is somewhat longer than that of the eagle, but is it really bald? It seems that many exegetes did not take a look at the bird itself, but just had a 'typical' picture of a vulture in their mind, maybe the Nubian or lappet-faced vulture with its bare neck (see, for example, http: / / www.all-free-photos.com/show / show photo. php?idph=PI18498\&lang=en $)^{2}$

Does this text really mean that Israel is asked to make itself

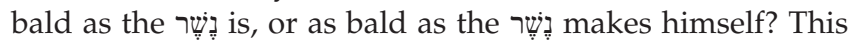
could then be understood as the moult of the birds, be it a vulture or an eagle. An eagle in his moult really looks bald (as the vulture does).

Another argument in favour of the vulture is found in Job 39:27-30. Here we read that the נֶֶֶ is to be found where the slain are (v. 30). This means that a נֶׁ would feed on carrion. Many scholars automatically conclude that tֶֶֶֶ therefore must be translated 'vulture', at least in this passage.

According to Pinney, there are four species of eagle found in Palestine: the Golden Eagle, the Lesser Spotted Eagle, the Imperial Eagle and the Serpent Eagle (Pinney 1964:147)3. They all are hunters, but - with the exception of the Serpent Eagle - all of them also feed on carrion (Watson

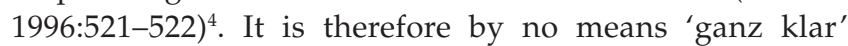
(absolutely clear), as Christoph Dohmen in his recent commentary on Deuteronomy claims, that Micah 1:16 and Job 39:27-30 can be referring only to the vulture, not the eagle, and that therefore the Hebrew term נֶֶׁ always means the vulture (with the possible exception of a few passages, where it may just denote generally one of the great birds of prey) (Dohmen 2004:57) .

2.The Zulu have a proverb which says: 'Do you see for the first time a vulture with feathers plucked from the neck?' (Nyembezi 1954:87).

3.Walter C. Kaiser speaks of eight species of eagle in Syria, Palestine and Arabia, but he does not specify them (Kaiser 2008:472).

4.The Golden Eagle, the Lesser Spotted Eagle and the Imperial Eagle all belong to the so-called 'true eagles' (Aquila). George Watson writes in his article in Encyclopedia American: 'They also often harass other birds to give up their own prey, and they eat carrion' (Watson 1996:522).

5.See also Botterweck et al. (eds 1986:682f).
This does not mean that iֶ in the OT does refer exclusively to the eagle. We should never forget that the Bible is not a handbook of biology or nature. Nature is described in the Bible always from the perspective of the observer. It is therefore to be expected that a term such as for great birds of prey that look and behave similarly and so include eagles and vultures.

Milton Fisher, in his article on בֶּ in the Theological wordbook of the Old Testament, writes:

Actually, not only did the Semitic languages tend to lump the large soaring birds into one family, but the Encyclopaedia Britannica defines 'eagle' as inclusive of several day-flying birds of prey comprising, along with hawks, harriers and old-world vultures, the family Acciptridae. (Fisher 1980:606-607)

It is therefore advisable to understand נֶשֶׁר not as a term defining a special species of birds, but a term which inspires a special picture and feeling in the reader. It means a great bird of prey, with the association of speed, strength, security and care, as we have already seen. Since there is no actual need to translate נֶׁ in any passage in the OT with 'vulture' (as we have seen), it seems best to use the term 'eagle' as the translation in all cases, since the term 'vulture' is more associated with ugliness and disgust in many modern cultures. In Germany, no one would think of speed, strength, security and care when they hear the term 'vulture'. In Nigeria there is a proverb saying 'The vulture's foot spoils the soup' (Crystal 2006:237) and the Ashanti in Ghana say: 'The vulture has not a good name and its body has not a good smell' (Mieder 1986:510).

\section{Stirring up the nest?}

The next question we are going to look at is whether the eagle really stirs up his nest, as most translations render Deuteronomy 32:11. We have already seen that there are other translations - such as the Common English Bible - that read 'Like an eagle protecting its nest'. Interestingly, this is also the understanding of the Septuagint (LXX) which

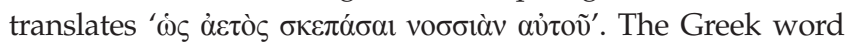

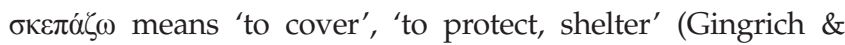
Danker 1958:753). ${ }^{6}$

The question therefore is whether the eagle 'taught its young to fly by throwing one out of the nest', as Peter C. Craigie claims (Craigie 1976:381). This could then be understood as a pedagogical act. The meaning would then be that God also 'taught Israel' (Farbridge 1970:82). Is this really the intention of this verse, though, especially when it is understood in its context, see especially verse 10 and verses 13-14, which speaks about the loving care of God towards his people Israel? Can the bringing of them out of Egypt be understood as teaching Israel to stand on its own two feet? This question is especially apt when we consider that the rest of the verse speaks about God and what he does on behalf of Israel!

6.The Jerusalem Talmud also translates 'as an eagle watches his nest' (Guggenheimer 2015:421). 
Michael A. Grisanti writes: 'Although many commentators

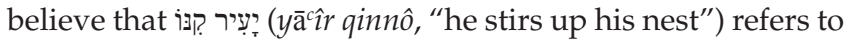
an aspect of an eagle's treatment of its young, others deny that an eagle disturbs its eaglets by chasing them out of the nest to force them to fly, though catching their young on adult wings if needed (Cansdale 143; A. Parmelee, All the Birds of the Bible [New Canaan, Conn.; Keats, 1959], 99; Peels, "On the Wings of the Eagle (Dtn 32, 11)," 300; contra Driver, 356)' (Grisanti 2012:786).

Hendrik G. L. Peels challenges the traditional understanding

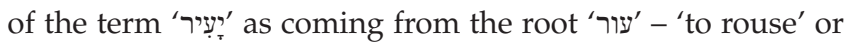

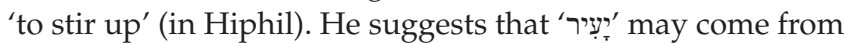
a different root, 'עיר', meaning 'to care for' or 'to guard over' (Peels 1994:301). This would be in accord with the translation of the LXX ('like an eagle protects his nest'). Koehler \& Baumgartner also support this suggestion in their dictionary of the OT (Koehler \& Baumgartner 2004:776). In their opinion this root would also be suitable for Job 8:6 where the translation 'If you are pure and upright, surely now $\mathrm{He}$ would rouse Himself for you and restore your righteous estate' could then be changed to '... surely now He would care for you and restore your righteous estate.'

It is not possible to decide this question with certainty. What seems to be clear, however, is that the idea of God acting pedagogically towards Israel seems to be wrong since this simply does not fit into the whole context of the verse. It seems better to follow the LXX and translate the verse as: 'Like an eagle, protecting its nest ...' This raises the question, though, of whether this protection also means that he carries them on his wings.

\section{Carrying its young?}

Exegetes differ greatly when it comes to the question of whether or not the eagle really carries its young on its back, as verse $11 \mathrm{~b}$ seems to indicate. Some definitely deny this possibility. Daniel I. Block, for example, claims: 'The common understanding of an adult eagle picking up its young, placing it on its pinions, and giving it a ride is fanciful and unnatural.' (Block 2012:754, Fn 34)7. Some are a bit less rigid, but still sceptical, as in the NIV Background Commentary: 'While Bible reference books often report how the eagle carries its young on its wings when they grow weary of flying, or catches them on their wings when they are fluttering in failure (see Dt 32:11), this behaviour has been difficult for naturalists to confirm through observation.' (Walton, Matthews \& Chavalas 2000:94) ${ }^{8}$.

Others maintain that there is indeed proof for such behaviour. Some simply state it as a fact without further proof (e.g. Braulik 1992:230; Christensen 2002:797; Craigie 1976:381; Farbridge 1970:82; Holzinger 1900:76; Merill 1994:414; Sarna 5751:103). Some (e.g. Christensen 2002:797; Tigay 5756:304) point to Samuel R. Driver, who reports different experiences 7.See also Dohmen 2004:58; Fisher 1980:607; Parmelee 1959:99.

8.Carl Friedrich Keil remarks that it is documented in unscientific literature (Keil 1983 [1878]:495 and Keil 1987 [1870]:562). of people who claim to have witnessed such behaviour (Driver 1902:358; Driver 1958:56-57). In an article in the Palestine Exploration Quarterly, Driver states with regard to Exodus 19:4 and Deuteronomy 32:11:

I wrongly ascribed these verses to the vulture because of the great span of its wings, forgetting that instances of the eagle carrying its young on its back or wings had been recorded. (Driver 1958:56)

He then goes on to cite two of these instances.

In his article, 'On the wings of the eagle - an old misunderstanding,' Hendrik G. L. Peels argues for another way to understand verse 11 . In his opinion, this verse divides into two very different halves. Verse 11a refers to the image of the eagle and its loving care for its young. Then the focus shifts and in verse $11 \mathrm{~b}$ God himself is the subject of all three verbs (Peels 1994:301, Fn 6). The carrying on the wings, then, is not something the eagle does (or at least not to that extent), it is something God does for Israel. Therefore the discussion of whether eagles really carry their young on their back is not really vital for the understanding of Deuteronomy 32:11. To examine this idea further we will now turn to the exegetical structure of verse 11 .

\section{The exegetical structure of verse 11}

\section{The context}

The immediate context of our verse starts in verse 9: Israel belongs to Yahweh, it is his heritage. Verse 10 then goes on to declare that God found Israel in the desert and cared for them with loving providence. Israel was the apple of God's eye. Then follows verse 11, where we first find the picture of the eagle as a symbol for God's loving care; and in verse $11 \mathrm{~b}$ we see how God applied this loving care to his people. Verses 12-14 further develop this idea and show how God provided Israel with everything it needed. The whole context, therefore, is a context of love, care and provision. We will now look at the two parts of verse 11 and see how they fit into the context.

\section{The chiastic structure of verse $11 \mathrm{a}$}

The first half of verse 11 has a clear chiastic structure:

\begin{tabular}{|c|c|}
\hline קִּוּ & רְעִיר \\
\hline 'ירַחַף & עַל־גוּזָדָליו \\
\hline
\end{tabular}

Two things are said about the eagle: He cares for his nest (or stirs it up) and he hovers over his young. ${ }^{9}$ This statement in verse $11 \mathrm{a}$ is obviously poetic and depicts the eagle.

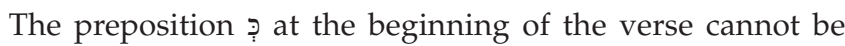
related to the verses before. Verse 10 has its own selfcontained simile ('He guarded him like the apple of his

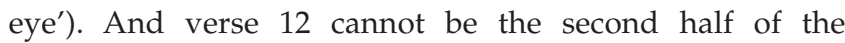
comparison because the idea of Yahweh guiding Israel is not

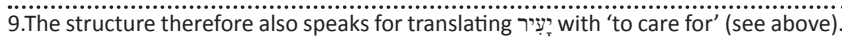


the counterpart to the whole of verse 11. Therefore it is reasonable to conclude that the first half of verse 11 is being compared to the second half, where both the subject and the object change.

\section{The change of subject and object in verse 11b}

While in verse 11a the object is plural (the young), in verse $11 \mathrm{~b}$ it is singular, now matching the gender and number of the only other object in the immediate context, namely Israel. In light of this we can conclude that it is only verse 11a where the eagle is the subject, while in verse $11 \mathrm{~b}$ it is God himself. As the eagle cares for his young (v. 11a), so too does God care for his people (v. 11b) (comp. Peels 1994:301, Fn 6).

\section{The 'wings'}

Three verbs are used in v. 11b: God 'spreads' his wings, 'takes' Israel and 'carries' them on his wings. The first phrase uses the common word for 'wings': The picture of God spreading his wings over his people is a picture of protection and care, as we have already seen. The second word for 'wings' is a different one: It is used only four times in the OT (Dt 32:11; Job 39:13; Ps 68:14 and 91:410), and in all

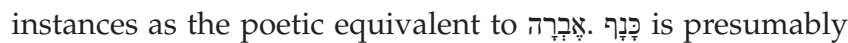
related to אַבִיר ('strong', 'mighty' Gesenius 2013:7). ${ }^{11}$ The idea of 'strength', therefore, is connected with this word. While כָָָּ stands for protection, אָרָרָ stands for strength. In this case it is the strength to carry someone on his wings, whisking them away from any threat they may be confronted with. Speed, strength, security and care, the elements connected with the image of an eagle, are therefore attributed to God in his relation to Israel in this verse.

\section{Conclusion}

Deuteronomy 32:9-14 speaks about God's loving care for his people of Israel. Verse 11 starts with the picture of an eagle ${ }^{12}$. This eagle cares ${ }^{13}$ for his young and hovers over them. In the same way, God himself spread his wings over his people, sheltering them under his protection. In the face of enemies and danger, God took Israel and put them on his wings and lifted them away from all danger.

\section{As Hendrik G. L. Peels says:}

But what the eagle cannot do, that the Lord YHWH does: He spreads his wings out, takes his 'young' up, and carries them ... The carrying 'as on eagle's wings' is a picture of God's watchful, loving care for Israel during the wilderness journey.' (Peels 1994:302)

10.In four other instances we find the masculine form (Job 39:26; Ps 55:7; is 30:31 and Ezk 17:3). In these instances there is no equivalent word for 'wings' in the text. In all cases the word is connected with the impression of great strength.

11.Koehler \& Baumgartner sees a common root אבר | (Koehler \& Baumgartner 2004:6), see also Robert L. Alden in his article in Theological wordbook of the Old Testament (Alden 1980:8).

12.This might be either an eagle or the Griffon vulture, but for the picture itself this is of no consequence. Since the eagle - as opposed to the vulture - evokes strong positive emotions, it is best to stick with the translation 'eagle'.

13.As we have seen, the Hebrew term which usually is translated 'to stir up' could also come from another root with the meaning 'to care for'. This seems to be more in line with the whole argumentation in this text.

\section{Acknowledgements Competing interests}

The author declares that he has no financial or personal relationships which may have inappropriately influenced him in writing this article.

\section{References}

Alden, R.L., 1980, 'אבר', in R.L. Harris, G.L. Archer \& B. Waltke, (Eds.), Theological wordbook of the Old Testament, pp. 8-9, Moody Press, Chicago.

Block, D., 2012, Deuteronomy, Zondervan, Grand Rapids. (The NIV Application Commentary, 4).

Botterweck, G. Johannes, Ringgren, Helmer, Fabry, Heinz Josef, (Eds.), 1986, Theologisches Wörterbuch zum Alten Testament, Kohlhammer, Stuttgart, (vol 5).

Bovon, F., 1996, Das Evangelium nach Lukas: 2. Teilband Lk 9,51-14,35, Benziger, Zürich, (in EKK, vol III/2).

Braulik, G., 1992, Deuteronomium II: 16,18 - 34,12, Echter Verlag, Würzburg, (in Neue Echter Bibel-Kommentar zum Alten Testament mit der Einheitsübersetzung, vol. 5,2).

Christensen, D.L., 2002, Deuteronomy 21:10-34:12, Thomas Nelson Publishers, Nashville, (in Word Biblical Commentary, vol. 6b)

Craigie, P.C., 1976, The Book of Deuteronomy, William B. Eerdmans, Grand Rapids, Michigan, (in The New International Commentary on the Old Testament, vol. 5).

Crystal, D., 2006, As they say in Zanzibar: Proverbial wisdom from around the world, Collins, London.

Dohmen, C., 2004, Exodus 19-40: Übersetzt und ausgelegt von Christoph Dohmen, Herder, Freiburg, Basel, Wien, (in Herders Theologischer Kommentar zum Alten Testament, vol. 2,2).

Driver, S.R., 1958, 'Once again: Birds in the Bible', Palestine Exploration Quarterly 19, 56-58.

Driver, S.R., 1902, A Critical and Exegetical Commentary on Deuteronomy, 3rd eition, T \& T Clark, Edinburgh, (in The International Critical Commentary, vol 5).

Dröscher, V.B., 1978, Die Tierwelt unserer Heimat: Faszinierende Ergebnisse der Verhaltensforschung, Hoffmann und Campe, Hamburg.

Farbridge, M.H., 1970, Studies in Biblical and Semitic symbolism, KTAV Publishing House, New York, (in The Library of Biblical Studies).

Fisher, M.C., 1980, 'נשׁר', in R.L. Harris, G.L. Archer \& B. Waltke, (Eds.), Theological wordbook of the Old Testament, pp. 606-607, Moody Press, Chicago.

Gesenius, W., 2013, Hebräisches und Aramäisches Handwörterbuch über das Alte Testament, 18th. edition, Springer, Berlin.

Gingrich, W.F. \& Danker, F.W., 1958, A Greek-English Lexicon of the New Testament and other early Christian literature: A translation and adaptation of the fourth revised and augmented edition of Walter Bauer's Griechisch-Deutsches Wörterbuch und der übrigen urchristlichen Literatur, 2nd edition, revised and augmented, The University of Chicago Press, Chicago, London.

Grisanti, M.A., 2012, 'Deuteronomy', in T. Longman III \& D.E. Garland, (Eds.), The Expositor'S Bible commentary: Numbers - Ruth, pp. 457-814, Zondervan, Grand Rapids, Michigan, (in The Expositor's Bible Commentary, vol. 2).

Guggenheimer, H.W., 2015, The Jerusalem Talmud: Second Order: Mo'ed. Edition, translation and commentary by Heinrich W. Guggenheimer, De Gruyter, Berlin, Boston, (in Studia Judaica: Forschungen zur Wissenschaft des Judentums, vol. 85).

Holzinger, H., 1900, Exodus, Verlag von J. C. B. Mohr (Paul Siebeck), Tübingen, Freiburg i. B., Leipzig, (Kurzer Hand-Commentar zum Alten Testament, vol. 2).

Kaiser, W.C. Jr., 2008, 'Exodus', in T. Longman III \& D.E. Garland, (Eds.), The Expositor's Bible commentary: Genesis-Leviticus, pp. 333-562, Zondervan, Grand Rapids, Michigan, (in The Expositor's Bible Commentary, vol. 1).

Keil, C.F., 1983 [1878], Genesis und Exodus, 4th edition, Reprint 3rd edition, BrunnenVerlag, Gießen, Basel, (in Biblischer Kommentar über das Alte Testament, vol 1).

Keil, C.F., 1987 [1870], Leviticus, Numeri und Deuteronomium, 3rd edition, Reprint 2nd edition, Brunnen-Verlag, Gießen, Basel, (in Biblischer Kommentar über das Alte Testament, vol 2).

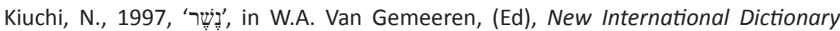
of Old Testament theology \& exegesis, pp. 200-201, Zondervan, Grand Rapids, Michigan, (vol. 3).

Koehler, L. \& Baumgartner, W., 2004, Hebräisches und Aramäisches Lexikon zum Alten Testament, 3rd edition 2 vols, Brill, Leiden, Boston, (vol. 1).

Merill, E.H., 1994, Deuteronomy, Broadman \& Holtman Publishers, [Nashville], (in The New American Commentary, vol. 4).

Mieder, W., 1986, The Prentice Hall Encyclopedia of World proverbs, Prentice Hall, Inc, Englewood Cliffs.

Nyembezi, C.L.S., 1954, Zulu proverbs, Witwatersrand University, Johannesburg.

Parmelee, A., 1959, All the birds of the Bible: Their stories, identification and meaning, Lutterworth Press, London. 
Peels, H.G., 1994, 'On the wings of the eagle (Dtn 32:11) - An old misunderstanding', Zeitschrift für die Alttestamentliche Wissenschaft 106, 300-303.

Pinney, R., 1964, The animals in the Bible: The identity and natural history of all the

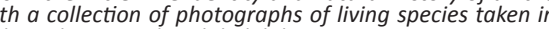
the Holy Land by the author, Chiton Books, Philadelphia.

Propp, W.H.C., 2006, Exodus 19-40: A new translation with introduction and commentary, Doubleday, Randoum House, New York, London, Toronto, Sydney, Auckland, (in The Anchor Bible, vol. 2,2).

Sarna, N.M., 5751, Exodus: Šěmôt, 1st edition, [Reprint], Jewish Publication Society, Philadelphia, (in The JPS Torah commentary, the traditional Hebrew text with M. Sarna, vol. 2).
Strack, H. \& Billerbeck, P., 1924, Das Evangelium nach Markus, Lukas und Johannes und die Apostelgeschichte: Erläutert aus Talmud und Midrasch, C. H. Beck, München, (in Kommentar zum NeuenTestament aus Talmud und Midrasch, vol. 2)

Tigay, J.H., 5756, Deuteronomy: Děbārîm. 1st edition, Jewish Publication Society, Philadelphia, (in The JPS Torah commentary, the traditional Hebrew text with the new JPS translation/The Jewish Publication Society. General edition Nahum M. Sarna; vol. 5).

Walton, J.H., Matthews, V.H. \& Chavalas, M.W., 2000, The IVP Bible background commentary: Old Testament, InterVarsity Press, Downers Grove.

Watson, G.E., 1996, 'Eagle', The Encyclopedia Americana: International Edition, pp. 520-522, Grolier Incorporated, Danbury, Connecticut, (vol. 9). 